\title{
Effects of dietary rapeseed meal and peas on the performance and meat quality of broilers
}

\author{
Petra Tuunainen ${ }^{1}$, Erja Koivunen ${ }^{1}$, Jarmo Valaja ${ }^{1,2}$, Eija Valkonen ${ }^{1,3}$, Jaakko Hiidenhovi ${ }^{1}$, Tuomo Tupasela ${ }^{1,}$ Marja \\ Hongisto ${ }^{4}$ \\ ${ }^{1}$ Luke Natural Resources Institute Finland, Green Technology, 31600 Jokioinen, Finland \\ ${ }^{2}$ Current Address: University of Helsinki, Department of Agricultural Sciences, 00014 University of Helsinki, Finland \\ ${ }^{3}$ Current Address: Hankkija-Maatalous Oy, 05801 Hyvinkää, Finland \\ ${ }^{4}$ Raisioagro Oy, 21201 Raisio, Finland \\ e-mail: petra.tuunainen@luke.fi
}

\begin{abstract}
Performance, meat quality and litter quality were determined in 4000 male and female Ross 308 broilers fed on starter diet (soybean meal or rapeseed meal and peas) and grower-finisher diets based on either soybean meal (control) or substituting rapeseed meal or rapeseed meal and pea in different proportions (100/0\%, $75 / 25 \%$ or $50 / 50 \%)$ for soybean meal in iso-nitrogenous basis. Performance of the birds fed with soybean meal diets was superior compared to that of the birds fed with rapeseed meal and pea based diets. Bird performance was the poorest and mortality the highest for the birds fed with the rapeseed meal grower diet. In this experiment birds did not reach performance target for the age and strain of bird. Overall, diet based solely on rapeseed meal protein is not suitable for broiler production. However, dietary rapeseed meal inclusion clearly improved fatty acid profile of breast meat. The omega-6/omega-3-ratio was 4.1, 2.4 and 2.7 for soybean meal, rapeseed meal, and rapeseed meal and peas based diets, respectively. There were no differences in sensory quality evaluation of breast meat between the treatments.
\end{abstract}

Key words: rapeseed, pea, broiler, performance, meat quality

\section{Introduction}

Soybean meal is the most commonly used protein source in broiler diets. Because the globally increasing demand and price of the soybean, it is necessary to find alternative protein sources to substitute for soybean meal. Imported protein increases the risk of salmonella infection, and the use of genetically modified soybean has also concerned consumers.

Legumes, such as peas and faba beans, have an amino acid profile which is relatively well balanced and have been used in broiler diets (Cowieson et al. 2003, Moschini et al. 2004). The nutritive value of peas, however, is limited by a number of antinutritive factors (ANFs), such like tannins, trypsin inhibitors, lectins, saponins, phytic acid and starches (Cowieson et al. 2003, McNeill et al. 2004). These ANFs reduce the nutritive value of pea meals by impairing nutrient utilization (Cowieson et al. 2003). ANFs are anti-nutritional because they are not degraded in gastrointestinal (GI) track or they degrade only partly. For example the digestibility of starches is dependent on the structure of the starch, their chemical properties, amylose to amylopectin ratio and how it interacts with other feed constituents. All methods or processes which will reduce ANFs in feed will enhance performance. Exogenous enzymes such as xylanases and $\beta$-glucanases or heat treatment such as pelleting, can be used to reduce ANFs. The exogenous enzymes supplement enzymes and provide hydrolytic capacity to the digestive tract. Xylanases and $\beta$-glucanases increase the digestibility of wheat and barley based diets (Bedford \& Schulze 1998). Xylanases and $\beta$-glucanases can degrade plant cell walls which are not normally degraded in bird's GI track because of their structure of xylans, $\beta$-glucans, cellulose, starch and protein. Xylans reduce also the anti-nutritive effects associated with wheat arabinoxylans.

Rapeseeds can be used in broiler diets as whole or ground full-fat rape seed (Barbour and Sim 1990, Fasina and Campbell 1997, McNeill et al. 2004, Szymeczko et al. 2010) or as pressed or extracted rapeseed cake or meal (Bell 1993, Kocher et al. 2001). Rape is rich in sulfur-containing amino acids, methionine and cystine, and threonine, and complements well the amino acid composition of pea (Barbour and Sim 1990). Rapeseed meal also includes glucosinolates (Chen and Andreasson 2001, McNeill et al. 2004). Glucosinolates are sulfur- and nitrogen-containing plant secondary metabolites that upon hydrolysis by endogenous myrosinases produce several different products (Halkier and Gershenzon 2006). Glucosinolates are common in the Brassicaceae and related plant families. The hydrolysis products have many different biological activities, e.g., as defense compounds and attractants (Chen and Andreasson 2001, Halkier and Gershenzon 2006). For humans these compounds function as cancer-preventing agents, biopesticides and flavor compounds. However, in rapeseed meal the presence of glucosinolate hydrolysis 
products, especially 5-vinyloxazolidine2-thione, causes gointogenic problems in thyroid and hepatic functions (Chen and Andreasson 2001, McNeill et al. 2004). Previous studies indicate that rapeseed meal low in glucosinolates (double zero and triple zero varieties) could replace part of the soybean meal without any detrimental effects on broiler performance (Fasina and Campbell 1997, Kocher et al. 2001, McNeill et al. 2004, Taraz et al. 2006, Toghyani et al. 2009). Also heat treatment such as pelleting decreases the level of ANFs in rapeseed meal.

In addition, rapeseed meal contains plenty of fibre, which may reduce the digestibility of the meal. Especially rapeseed husks are rich in fibre. Rape seeds contain a relatively more husks (15-22\%) than soybeans (6-8\%) (Jeroch et al. 2001). If husks are separated before oil extraction by mechanical means, the crude fibre content is lower and more suitable to monogastric animals. According to Jeroch et al. (2001) from $117 \mathrm{~g} \mathrm{~kg}^{-1} \mathrm{DM}$ (dry matter) of normal rapeseed meal to $72 \mathrm{~g} \mathrm{~kg}^{-1} \mathrm{DM}$ of de-hulled rapeseed meal. They also found that rapeseed meal from de-hulled seeds had increased content of metabolized energy, crude protein and crude fat as well as lysine, threonine and methionine. De-hulling is not a common practice in Finland yet, so in this experiment we used rapeseed meal with husks. Also reducing the husk proportion of the plant by breeding alters the fibre content.

Especially the high content of non-starch polysaccharides (NSP) may result in increased faeces viscosity as monogastric digestive enzymes do not degrade the NSP. The NSP content varies accordingly to species and cultivars (Kocher et al. 2001, Moschini et al. 2004). Rapeseed oil is rich in unsaturated fatty acids like omega-3 fatty acids. The fatty acid composition of poultry meat is an important quality parameter especially with respect to potentially affecting human health from poultry meat consumption (Mantzioris et al. 2000, Rahimi et al. 2011).

The objective of this study was to find out the effects of diets with high content of rapeseed meal and pea on broiler production and meat quality.

\section{Materials and methods}

\section{Birds and housing}

A total of 40001 day-old Ross 308 broiler chickens were reared in 48 peat litter floor pens ( $2 \mathrm{~m} \times 2 \mathrm{~m}$ ) with 83 broilers (half females and half males) in each for 34 days. There were 7 replicates (pens) for each treatment group except the control group which had only 6 replicates. Birds were sex sorted in hatchery before arriving. Birds received experimental starter diets from $d 1$ to $d 7$ and the first grower diets from $d 8$ to $d 21$, the second grower diets from d 22 to $d 29$ and finisher diets from d 30 to $d 34$. The temperature and lighting were controlled according to Ross broiler breeder instructions. During the first $2 \mathrm{~d}$ of experiment, the temperature was $35^{\circ} \mathrm{C}$, and during the rest of the first week the temperature was $30^{\circ} \mathrm{C}$. From the beginning of the second week, the temperature was reduced by $3^{\circ} \mathrm{C}$ per week until it was $20^{\circ} \mathrm{C}$. Relative humidity and ventilation were arranged under standard conditions. Light was provided for $14.5 \mathrm{~h}$ light and $8 \mathrm{~h}$ dark cycles with 1.5 - $\mathrm{h}$ dimming time.

\section{Diets}

The diets consisted of wheat, soybean meal or rapeseed meal and/or pea, rapeseed oil, minerals, vitamins, amino acids, $0.01 \%$ Roxazyme G2 ${ }^{\circledR}$ enzyme (DSM Nutritional Products Ltd, Switzerland), $0.07 \%$ Betafin ${ }^{\circledR}$ (Danisco Animal Nutrition, United Kingdom) and Elancoban200 coccidiostat (Table 1 and 2). Both rapeseed (cv. Cordelia) and pea (cv. Karita) varieties used in this study are commonly cultivated in Finland and used for feeding dairy cows. Feed samples from wheat, soybean, rapeseed and pea meals were taken from every batch made and then pooled. The pooled samples were passed through a hammer mill fitted with a 1-mm mesh prior to analysis (Table 3). Finisher diets did not contain coccidiostat. Roxazyme $\mathrm{G}^{\circledR}{ }^{\circledR}$ and Betafin ${ }^{\circledR}$ enzymes were included in every diet to improve birds' production, weight gain and support the function of coccidiostat. Experimental diets were formulated to meet the nutrient requirements (Luke 2014). The starter diet was pelleted with $3 \mathrm{~mm}$ die and the grower and finisher diets with $4 \mathrm{~mm}$ die. All feeds were heated and pelleted. The heating might reduce ANFs in rapeseed and pea meal. Feed and water were offered ad libitum throughout the study. 
P. Tuunainen et al. (2016) 25: 22-33

Table 1. Ingredients $\left(\mathrm{g} \mathrm{kg}^{-1}\right)$ of experimental diets

\begin{tabular}{|c|c|c|c|c|c|c|c|c|c|c|c|c|c|c|}
\hline \multirow[b]{2}{*}{ Groups } & \multicolumn{2}{|c|}{ Starter diet } & \multicolumn{4}{|c|}{ Grower diet 1} & \multicolumn{4}{|c|}{ Grower diet 2} & \multicolumn{4}{|c|}{ Finisher diet } \\
\hline & $1-4$ & $5-7$ & 1 & $2+5$ & $3+6$ & $4+7$ & 1 & $2+5$ & $3+6$ & $4+7$ & 1 & $2+5$ & $3+6$ & $4+7$ \\
\hline Treatments & C & $R+P$ & C & R100 & $\begin{array}{l}\text { R75/ } \\
\text { P25 }\end{array}$ & $\begin{array}{l}\text { R50/ } \\
\text { P50 }\end{array}$ & C & R100 & $\begin{array}{l}\text { R75/ } \\
\text { P25 }\end{array}$ & $\begin{array}{l}\text { R50/ } \\
\text { P50 }\end{array}$ & C & R100 & $\begin{array}{l}\text { R75/ } \\
\text { P25 }\end{array}$ & $\begin{array}{l}\text { R50/ } \\
\text { P50 }\end{array}$ \\
\hline \multicolumn{15}{|l|}{ Ingredients } \\
\hline Wheat & 657.2 & 366.3 & 701.9 & 583.7 & 519.8 & 445.7 & 743.9 & 636.2 & 582.1 & 518.5 & 744.4 & 636.7 & 582.6 & 519.0 \\
\hline $\begin{array}{l}\text { Rapeseed } \\
\text { meal }\end{array}$ & 0.0 & 245.0 & 0.0 & 330.0 & 267.0 & 193.0 & 0.0 & 284.6 & 229.7 & 165.9 & 0.0 & 284.6 & 229.7 & 165.9 \\
\hline Pea & 0.0 & 300.0 & 0.0 & 0.0 & 135.0 & 293.0 & 0.0 & 0.0 & 116.4 & 252.2 & 0.0 & 0.0 & 116.4 & 252.2 \\
\hline Soybean meal & 275.0 & 0.0 & 245.0 & 0.0 & 0.0 & 0.0 & 206.0 & 0.0 & 0.0 & 0.0 & 206.0 & 0.0 & 0.0 & 0.0 \\
\hline Rapeseed oil & 16.4 & 40.0 & 3.5 & 40.0 & 31.0 & 20.2 & 2.5 & 34.8 & 26.7 & 17.5 & 2.5 & 34.8 & 26.7 & 17.5 \\
\hline $\begin{array}{l}\text { Monocalsium } \\
\text { phosphate }\end{array}$ & 21.3 & 20.4 & 20.1 & 18.5 & 19.0 & 19.5 & 19.1 & 17.8 & 18.2 & 18.6 & 19.1 & 17.8 & 18.2 & 18.6 \\
\hline Limestone & 13.3 & 10.7 & 14.1 & 10.3 & 11.1 & 12.1 & 14.1 & 10.7 & 11.4 & 12.3 & 14.1 & 10.7 & 11.4 & 12.3 \\
\hline Salt & 4.0 & 4.0 & 4.0 & 4.0 & 4.0 & 4.0 & 4.0 & 4.0 & 4.0 & 4.0 & 4.0 & 4.0 & 4.0 & 4.0 \\
\hline $\begin{array}{l}\text { Mineral } \\
\text { premix }^{1}\end{array}$ & 2.0 & 2.0 & 2.0 & 2.0 & 2.0 & 2.0 & 2.0 & 2.0 & 2.0 & 2.0 & 2.0 & 2.0 & 2.0 & 2.0 \\
\hline $\begin{array}{l}\text { Vitamin } \\
\text { premix }^{2}\end{array}$ & 2.0 & 2.0 & 2.0 & 2.0 & 2.0 & 2.0 & 2.0 & 2.0 & 2.0 & 2.0 & 2.0 & 2.0 & 2.0 & 2.0 \\
\hline $\begin{array}{l}\text { DL- } \\
\text { Methionine }\end{array}$ & 1.7 & 2.2 & 1.4 & 1.5 & 1.7 & 2.0 & 1.2 & 1.2 & 1.4 & 1.6 & 1.2 & 1.2 & 1.4 & 1.6 \\
\hline L-Lysine & 5.2 & 4.9 & 4.3 & 5.9 & 5.1 & 4.1 & 4.3 & 5.5 & 4.8 & 4.0 & 4.3 & 5.5 & 4.8 & 4.0 \\
\hline Threonine & 1.4 & 2.0 & 1.2 & 1.7 & 1.8 & 1.9 & 0.4 & 0.7 & 0.8 & 1.0 & 0.4 & 0.7 & 0.8 & 1.0 \\
\hline Elancoban200 & 0.5 & 0.5 & 0.5 & 0.5 & 0.5 & 0.5 & 0.5 & 0.5 & 0.5 & 0.5 & 0.0 & 0.0 & 0.0 & 0.0 \\
\hline
\end{tabular}

$\mathrm{C}=100 \%$ of the protein of the diet is from soybean meal; R100 $=100 \%$ of the protein from soybean meal in control diet replaced with protein from rapeseed meal; R75/P25 $=25 \%$ of the protein from rapeseed meal in diet R100 replaced with protein from peas; R50/P50 $=50 \%$ of the protein from rapeseed meal in diet R100 replaced with protein from peas; ${ }^{1}$ Providing the following per $\mathrm{kg}$ of feed: Ca $0.6 \mathrm{~g}$, Fe $25 \mathrm{mg}$, Cu 8 $\mathrm{mg}$, Mn $50 \mathrm{mg}$, Zn $65 \mathrm{mg}$, I $0.5 \mathrm{mg}$, Se $0.2 \mathrm{mg}$; ${ }^{2}$ Providing the following per kg of feed: Ca $2.4 \mathrm{mg}$, vitamin A $23.958 \mathrm{IU}$ (retinol), vitamin D $5.476 \mathrm{IU}$, vitamin E $61.6 \mathrm{IU}$, $\alpha$-tokopherol $56.1 \mathrm{mg}$, vitamin $\mathrm{K}_{3} 10.5 \mathrm{mg}$, vitamin $\mathrm{B}_{1} 4.8 \mathrm{mg}$, vitamin $\mathrm{B}_{2} 10.5 \mathrm{mg}$, vitamin $\mathrm{B}_{6} 7.4 \mathrm{mg}$, vitamin $\mathrm{B}_{12}{ }^{3}$ $0.04 \mathrm{mg}$, biotin $0.4 \mathrm{mg}$, folic acid $1.3 \mathrm{mg}$, niacin $84.2 \mathrm{mg}$, pantothenic acid $21.1 \mathrm{mg}$, canthaxanthin $5.7 \mathrm{mg}$

Table 2. Calculated and analysed chemical composition ( $\mathrm{g} \mathrm{kg}^{-1} \mathrm{DM}$, except DM and AME) of experimental diets

\begin{tabular}{|c|c|c|c|c|c|c|c|c|c|c|c|c|c|c|}
\hline \multirow[b]{2}{*}{ Groups } & \multicolumn{2}{|c|}{ Starter diet } & \multicolumn{4}{|c|}{ Grower diet 1} & \multicolumn{4}{|c|}{ Grower diet 2} & \multicolumn{4}{|c|}{ Finisher diet } \\
\hline & $1-4$ & $5-7$ & 1 & $2+5$ & $3+6$ & $4+7$ & 1 & $2+5$ & $3+6$ & $4+7$ & 1 & $2+5$ & $3+6$ & $4+7$ \\
\hline Treatments & C & $\mathrm{R}+\mathrm{P}$ & $\mathrm{C}$ & R100 & $\begin{array}{l}\text { R75/ } \\
\text { P25 }\end{array}$ & $\begin{array}{l}\text { R50/ } \\
\text { P50 }\end{array}$ & C & R100 & $\begin{array}{l}\text { R75/ } \\
\text { P25 }\end{array}$ & $\begin{array}{l}\text { R50/ } \\
\text { P50 }\end{array}$ & $\mathrm{C}$ & R100 & $\begin{array}{l}\text { R75/ } \\
\text { P25 }\end{array}$ & $\begin{array}{c}\text { R50/ } \\
\text { P50 }\end{array}$ \\
\hline
\end{tabular}

Calculated composition

AME1, MJ

$\mathrm{kg}^{-1}$

Crude

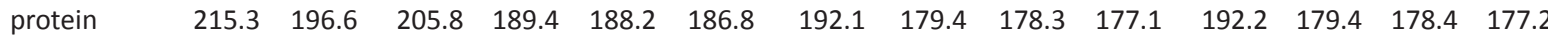

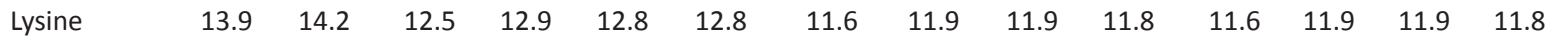

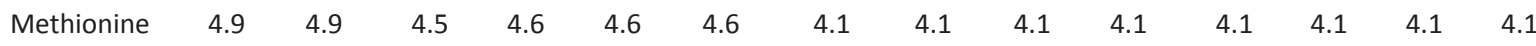

$\begin{array}{llllllllllllllll}\begin{array}{l}\text { Methionine+ } \\ \text { cysteine }\end{array} & 8.5 & 8.2 & 8.1 & 7.8 & 7.8 & 7.8 & 7.5 & 7.3 & 7.3 & 7.2 & 7.5 & 7.3 & 7.3 & 7.2\end{array}$

$\begin{array}{lllllllllllllll}\text { Threonine } & 8.9 & 9.1 & 8.3 & 8.6 & 8.6 & 8.5 & 7.0 & 7.2 & 7.2 & 7.2 & 7.0 & 7.2 & 7.2 & 7.2\end{array}$

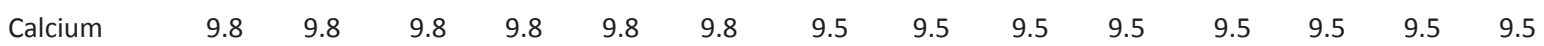

Phosphorus

$\begin{array}{lllllllllllllll}\text { (available) } & 4.8 & 4.8 & 4.6 & 4.6 & 4.6 & 4.6 & 4.4 & 4.4 & 4.4 & 4.4 & 4.4 & 4.4 & 4.4 & 4.4\end{array}$

Analyzed composition

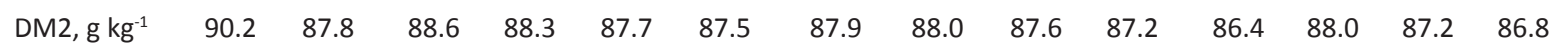

$\mathrm{g} \mathrm{kg}^{-1} \mathrm{DM}$

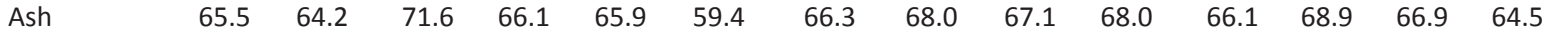

Crude

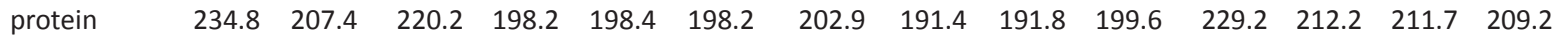

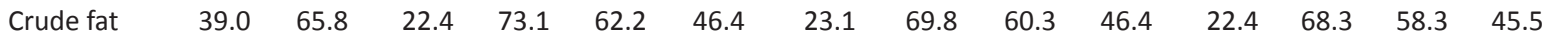

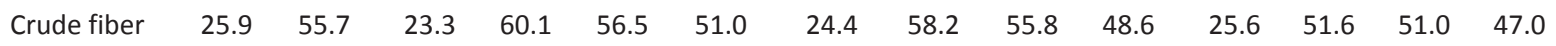

$\mathrm{C}=100 \%$ of the protein of the diet is from soybean meal; R100 $=100 \%$ of the protein from soybean meal in control diet replaced with protein from rapeseed meal; $\mathrm{R} 75 / \mathrm{P} 25=25 \%$ of the protein from rapeseed meal in diet $\mathrm{R} 100$ replaced with protein from peas; $\mathrm{R} 50 / \mathrm{P} 50=$ $50 \%$ of the protein from rapeseed meal in diet R100 replaced with protein from peas; AME = apparent metabolized energy; DM = dry matter 
Table 3. The analysed composition ( $\mathrm{g} \mathrm{kg}^{-1} \mathrm{DM}$, except DM) of wheat, soybean meal, rapeseed meal and pea meal used for experimental diets

\begin{tabular}{lcccc}
\hline & Wheat & Soybean meal & Rapeseed meal & Pea meal \\
\hline DM, kg $^{-1}$ & 89.02 & 86.79 & 87.34 & 84.82 \\
Ash & 21.40 & 69.60 & 71.80 & 32.20 \\
Crude protein & 138.80 & 528.80 & 376.80 & 244.00 \\
Crude fat & 18.50 & 12.30 & 51.80 & 12.70 \\
Crude fiber & 26.30 & 38.90 & 125.90 & 66.30 \\
\hline
\end{tabular}

DM = dry matter

\section{Experimental treatments}

Experimental treatments were:

1. Soybean meal based starter and grower diets (control)

2. Soybean meal starter diet and rapeseed meal grower diets (R100)

3. Soybean meal starter diet, and rapeseed meal and pea grower diets (the proportion of protein from rapeseed meal: protein from peas 75:25, R75/P25)

4. Soybean meal starter diet, and rapeseed meal and pea grower diets (the proportion of protein from rapeseed meal: protein from peas 50:50, R50/P50)

5. Rapeseed meal and pea starter diet and rapeseed meal grower diets (R100)

6. Rapeseed meal and pea starter diet, and rapeseed meal and pea grower diets (the proportion of protein from rapeseed meal: protein from peas 75:25, R75/P25)

7. Rapeseed meal and pea starter diet, and rapeseed meal and pea grower diets (the proportion of protein from rapeseed meal: protein from peas 50:50, R50/P50)

\section{Experimental procedures}

Samples were collected from each feed and were passed through a hammer mill fitted with a 1- mm mesh for analysis. Crude fat and ash were determined by standard methods (AOAC 1990). Crude fibre was determined with modified method (AOAC method 962.09) using glass wool instead of a ceramic fibre filter. Nitrogen content was analysed according to Dumas method (Leco Corporation, St. Joseph, MI). Crude protein content was calculated from nitrogen content multiplying it by 6.25. Metabolizable energy (ME, $\mathrm{MJ} \mathrm{kg}^{-1}$ ) was calculated from chemical analysis of feed ingredients.

Birds were weighed at the beginning, at 7 and $20 \mathrm{~d}$ of age, and at the end of the experiment at $34 \mathrm{~d}$ of age. Birds were weighted by pen, all birds together. The mean carcass weight for each pen was measured at the commercial slaughterhouse. The feed consumption was recorded by pen throughout the experiment. Samples were taken from the litter at the end of the experiment and analysed for dry matter content. Mortality and culling was recorded daily.

Two male broilers from each pen from treatment groups 1, 5, 6 and 7 were randomly selected, weighed and killed by neck dislocation at day 34. Males were chosen because in our consideration experimental diets could have bigger effect on males than females, because males grow faster and bigger. Also all slaughtered birds needed to be same sex. Birds' breast muscles and abdominal fat were weighed and the breast meat of one sample broiler from each pen (treatment groups 1, 5, 6 and 7, in total of 7 birds per treatment group, except 6 birds per control group) was used for sensory quality evaluation and the breast meat of the other sample broiler (also in total of 7 birds per treatment, except 6 birds per control) for fatty acid composition determination. The sensory evaluation of breast meat samples was performed using a seven point scale form, according to instructions of Meat Industry Research at Hämeenlinna, Finland. A panel of 10 people evaluated the taste, tenderness and juiciness of meat samples immediately after roasting. The fatty acid composition was analysed by using gas chromatography (Slover and Lanza 1979). In addition, thyroid glands were removed from sample birds in treatment groups 1 and 5 (in total of 12 birds from treatment group 1 and 14 birds from treatment group 5) and the glands were weighed. 
Cumulative mortality was calculated as follows:

Cumulative mortality

$$
\begin{aligned}
& =\left[\left[\text { Mortality }_{d 1} /\left(N-\left(\text { Mortality }_{d 0}+\text { Mortality }_{d 1}\right)\right)\right] \times 100\right] \\
& +\left[\left[\text { Mortality }_{d 2} /\left(N-\left(\text { Mortality }_{d 1}+\text { Mortality }_{d 2}\right)\right)\right] \times 100\right]+\cdots
\end{aligned}
$$

Where $\mathrm{d}=$ mortality per group on day $\mathrm{x}$ and $\mathrm{N}=$ number of birds per group

Experimental data was subjected to analysis of variance using the GLM procedure of SAS (1990). Differences between the diets were tested using single degree of freedom orthogonal contrasts defined as C1 = effect of replacing soybean meal protein with protein from rapeseed meal and peas (treatment 1 vs. treatments 2, 3, 4, 5, 6 and 7), C2 = effect of starter diets (treatments 2,3 and 4 vs. treatments 5, 6 and 7), C3 = effect of replacing a part of rapeseed meal protein with protein from peas (treatments 2 and 5 vs. treatments $3,4,6$ and 7), C4 = effect of pea inclusion level (treatments 3 and 6 vs. treatment 4 and 7), C5 = interaction $\mathrm{C} 2{ }^{*} \mathrm{C} 3$ and $\mathrm{C} 6=$ interaction $\mathrm{C} 2{ }^{*} \mathrm{C} 4$.

\section{Results}

\section{Bird performance}

The effect of rapeseed meal and peas on broilers' body weight, carcass weight, growth, feed intake, feed conversion ratio, mortality and culling are shown in Tables 4 and 5. The results are shown by the experimental group, because body weight, carcass weight, feed intake and therefore feed conversion ratio were measured and calculated by pen, not separating birds of different sex from others. All birds in each pen weighted at the same time and had only one pan feeder per pen. Also mortality and culling were not recorded by sex. It was difficult to separate dead or culled males from females when birds were young. By the time of the slaughter, males were easier

\begin{tabular}{|c|c|c|c|c|c|c|c|c|}
\hline Groups & 1 & 2 & 3 & 4 & 5 & 6 & 7 & \\
\hline Treatment & C & R100 & R75/P25 & R50/P50 & R100 & R75/P25 & R50/P50 & \\
\hline Starter diet & SB & SB & SB & SB & $R+P$ & $R+P$ & $R+P$ & SEM \\
\hline \multicolumn{9}{|c|}{ Body weight, g } \\
\hline $7 d$ & $180.64^{\mathrm{a}}$ & $178.69^{\mathrm{a}}$ & $178.54^{\mathrm{a}}$ & $179.02^{\mathrm{a}}$ & $150.68^{c}$ & $154.33^{b}$ & $155.26^{\mathrm{b}}$ & 1.239 \\
\hline $20 d$ & $865.36^{a}$ & $712.02^{\mathrm{de}}$ & $781.53^{c}$ & $820.76^{b}$ & $625.87^{f}$ & $698.73^{e}$ & $729.17^{d}$ & 6.638 \\
\hline $34 \mathrm{~d}$ & $2037.55^{a}$ & $1609.46^{f}$ & $1812.26^{d}$ & $1958.61^{b}$ & $1565.02^{\mathrm{g}}$ & $1732.71^{e}$ & $1857.27^{c}$ & 12.04 \\
\hline $\begin{array}{l}\text { Carcass } \\
\text { weight, g }\end{array}$ & $1451.12^{\mathrm{a}}$ & $1084.24^{\mathrm{e}}$ & $1270.54^{c}$ & $1353.69^{b}$ & $1054.09^{e}$ & $1156.46^{d}$ & $1275.41^{c}$ & 12.367 \\
\hline \multicolumn{9}{|l|}{ Growth, g } \\
\hline $1-7 d$ & $137.98^{\mathrm{a}}$ & $136.42^{\mathrm{a}}$ & $136.10^{\mathrm{a}}$ & $136.68^{\mathrm{a}}$ & $108.33^{c}$ & $111.99^{b}$ & $112.88^{b}$ & 1.194 \\
\hline $8-20 d$ & $684.72^{\mathrm{a}}$ & $533.32^{\mathrm{e}}$ & $602.99^{c}$ & $641.74^{b}$ & $475.18^{f}$ & $544.40^{\mathrm{e}}$ & $573.91^{d}$ & 6.113 \\
\hline $1-34 d$ & $1994.89^{\mathrm{a}}$ & $1567.19^{f}$ & $1769.82^{d}$ & $1916.26^{\mathrm{b}}$ & $1522.67^{g}$ & $1690.37^{e}$ & $1814.90^{c}$ & 12.019 \\
\hline \multicolumn{9}{|c|}{ Feed intake, g/bird/day } \\
\hline $1-7 d$ & $20.50^{\mathrm{a}}$ & $20.49^{a}$ & $20.29^{a}$ & $20.34^{\mathrm{a}}$ & $18.78^{\mathrm{b}}$ & $18.40^{\mathrm{b}}$ & $18.72^{b}$ & 0.263 \\
\hline $8-20 d$ & $76.66^{\mathrm{a}}$ & $68.75^{c}$ & $72.18^{b}$ & $73.79^{b}$ & $61.54^{e}$ & $65.37^{d}$ & $65.39^{d}$ & 0.581 \\
\hline $1-34 d$ & $98.87^{\mathrm{a}}$ & $84.21^{\text {de }}$ & $90.70^{c}$ & $93.69^{b}$ & $76.58^{f}$ & $83.32^{\mathrm{e}}$ & $85.94^{d}$ & 0.804 \\
\hline \multicolumn{9}{|c|}{ FCR, kg feed/kg growth } \\
\hline $1-7 d$ & $1.04^{c}$ & $1.06^{\mathrm{c}}$ & $1.04^{c}$ & $1.04^{\mathrm{c}}$ & $1.22^{\mathrm{a}}$ & $1.16^{\mathrm{b}}$ & $1.16^{\mathrm{b}}$ & 0.015 \\
\hline $8-20 d$ & $1.46^{\mathrm{c}}$ & $1.64^{\mathrm{a}}$ & $1.55^{\mathrm{b}}$ & $1.49^{c}$ & $1.65^{\mathrm{a}}$ & $1.55^{\mathrm{b}}$ & $1.47^{c}$ & 0.012 \\
\hline $1-34 d$ & $1.69^{d}$ & $1.97^{\mathrm{a}}$ & $1.77^{\mathrm{c}}$ & $1.69^{d}$ & $1.92^{\mathrm{b}}$ & $1.74^{\mathrm{c}}$ & $1.68^{d}$ & 0.014 \\
\hline \multicolumn{9}{|c|}{ Mortality+ culling, \% } \\
\hline $1-7 d$ & 1.61 & 0.85 & 0.86 & 1.56 & 0.51 & 1.37 & 0.51 & 0.375 \\
\hline $8-20 d$ & $0.61^{\mathrm{e}}$ & $3.78^{\mathrm{cd}}$ & $1.03^{\mathrm{de}}$ & $0.70^{\mathrm{e}}$ & $13.83^{\mathrm{a}}$ & $5.36^{\mathrm{bc}}$ & $7.60^{\mathrm{b}}$ & 1.063 \\
\hline $1-34 d$ & $3.02^{\mathrm{d}}$ & $25.80^{\mathrm{b}}$ & $4.82^{\mathrm{d}}$ & $6.24^{d}$ & $32.82^{\mathrm{a}}$ & $14.69^{c}$ & $12.75^{\mathrm{c}}$ & 1.822 \\
\hline
\end{tabular}
to separate, because they had higher body weight and brighter coloured combs than females.

$\mathrm{C}=100 \%$ of the protein of the diet is from soybean meal; R100 $=100 \%$ of the protein from soybean meal in control diet replaced with protein from rapeseed meal; R75/P25 = 25\% of the protein from rapeseed meal in diet R100 replaced with protein from peas; R50/P50 = $50 \%$ of the protein from rapeseed meal in diet R100 replaced with protein from peas; ${ }^{a-d}=$ Means within rows with different superscripts are significantly different from each other by Tukey's test at $p<0.05 ; \mathrm{N}=7$ for groups $2-7$, for group $1 \mathrm{~N}=6$ and SEM $=1.08 *$ SEM 
Table 5. Contrasts of the broiler chicken performance in response to treatment diets

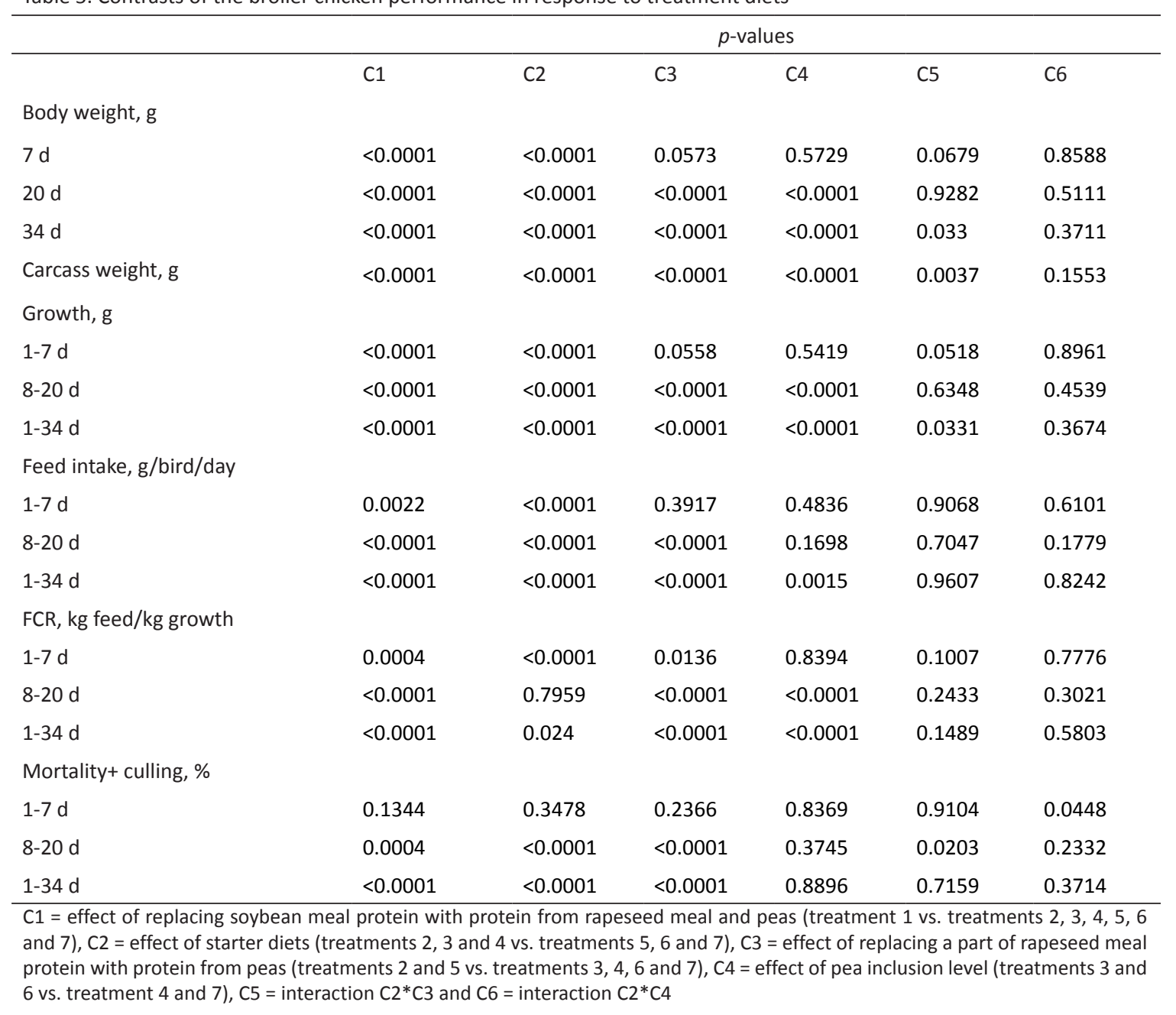

On the soybean meal starter diet birds grew faster and had higher body weight than the birds receiving the rapeseed meal and pea diet during the starter period ( 1 to7 days). Broilers had higher feed intake and lower feed conversion ratio (FCR) on soybean starter diet than on rapeseed meal and pea starter diet. All these results were statistically significant $(p<0.0001)$. There were no differences in mortality during starter period ( 1 to 7 days).

During growing period of 8 to 20 days the birds receiving the soybean meal based control diet had statistically significantly better performance than the birds in other treatment groups. The birds fed with rapeseed meal (R100, R75/P25 and R50/P50 were smaller and grew slower, had lower feed intake, higher FCR $(p<0.0001)$ and higher mortality $(p=0.0040)$ than the birds in the control group. When peas were added to grower diets (R75/P25 and R50/P50), birds' body weight was higher, growth rate was faster, feed intake was higher, FCR was better and mortality lower than that of birds receiving R100 diets $(p<0.0001)$. When pea was added $50 \%$, birds' performance was also significantly better than birds' receiving $25 \%$ pea meal, except FCR and mortality didn't differ between experiment groups fed with pea meal (R75/P25 and R50/P50).

Similar effects were seen in final results during whole experiment (1 to 34 days). The control group with soybean meal had the best performance when compared to other treatment groups. Birds' final weight and carcass weight were bigger, growth rate was faster, feed intake was higher, FCR was better and mortality lower, than that of the birds receiving experimental diets $(p<0.0001)$. Similarly to growing period, birds' performance was statistically significantly better when pea meal was added to diet (R100 vs. R75/P25 and R50/P50), except there were no differences in mortality between diets R75/P25 and R50/P50.

Cumulative mortality (\%) is reported in Table 6. Cumulative mortality was substantively high in treatment groups which received rapeseed and pea meal as a starter diet (groups 5, 6 and 7) and in group 2 which received 100\% rapeseed meal. 
Table 6. The effect of diets with soybean meal (SB), rapeseed meal (R), or rapeseed meal and peas ( $P$ ) on cumulative mortality of broilers

\begin{tabular}{|c|c|c|c|c|c|c|c|c|c|c|c|c|c|c|}
\hline Group & 1 & 2 & 3 & 4 & 5 & 6 & 7 & & & & & & & \\
\hline $\begin{array}{l}\text { Treat- } \\
\text { ment }\end{array}$ & $\mathrm{C}$ & R100 & $\begin{array}{l}\text { R75/ } \\
\text { P25 }\end{array}$ & $\begin{array}{l}\text { R50/ } \\
\text { P50 }\end{array}$ & R100 & $\begin{array}{l}\text { R75/ } \\
\text { P25 }\end{array}$ & $\begin{array}{l}\text { R50/ } \\
\text { P50 }\end{array}$ & & & & $p$-values & & & \\
\hline $\begin{array}{l}\text { Starter } \\
\text { diet }\end{array}$ & SB & SB & SB & SB & $R+P$ & $\mathrm{R}+\mathrm{P}$ & $R+P$ & SEM & $\mathrm{C} 1$ & $\mathrm{C} 2$ & C3 & C4 & C5 & C6 \\
\hline \multicolumn{15}{|c|}{ Cumulative mortality, $\%$} \\
\hline $0-7 d$ & 1.65 & 0.87 & 0.87 & 1.61 & 0.52 & 1.39 & 0.52 & 0.39 & 0.134 & 0.342 & 0.236 & 0.862 & 0.920 & 0.043 \\
\hline $7-14 d$ & $1.65^{\mathrm{ab}}$ & $1.22^{\mathrm{ab}}$ & $1.22^{\mathrm{ab}}$ & $1.79^{\mathrm{ab}}$ & $2.48^{\mathrm{a}}$ & $2.28^{\mathrm{a}}$ & $0.87^{b}$ & 0.47 & 0.994 & 0.230 & 0.450 & 0.379 & 0.153 & 0.042 \\
\hline $14-21 d$ & $2.28^{d}$ & $4.88^{\mathrm{cd}}$ & $1.93^{d}$ & $2.33^{d}$ & $16.50^{\mathrm{a}}$ & $7.30^{\mathrm{bc}}$ & $8.97^{b}$ & 1.29 & 0.003 & $<0.0001$ & $<0.0001$ & 0.425 & 0.016 & 0.624 \\
\hline $21-28 d$ & $2.69^{d}$ & $25.47^{b}$ & $3.90^{d}$ & $5.46^{d}$ & $38.76^{a}$ & $12.94^{c}$ & $14.42^{c}$ & 2.05 & $<0.0001$ & $<0.0001$ & $<0.0001$ & 0.462 & 0.234 & 0.984 \\
\hline $28-34 d$ & $3.11^{\mathrm{c}}$ & $32.67^{\mathrm{ab}}$ & $5.02^{\mathrm{c}}$ & $6.61^{c}$ & $44.45^{\mathrm{a}}$ & $39.34^{\mathrm{ab}}$ & $14.42^{b c}$ & 8.94 & 0.052 & 0.0181 & 0.007 & 0.199 & 0.552 & 0.146 \\
\hline
\end{tabular}

$\mathrm{C}=100 \%$ of the protein of the diet is from soybean meal; $\mathrm{R} 100=100 \%$ of the protein from soybean meal in control diet replaced with protein from rapeseed meal; R75/P25 = 25\% of the protein from rapeseed meal in diet R100 replaced with protein from peas; R50/P50 $=50 \%$ of the protein from rapeseed meal in diet R100 replaced with protein from peas; $C 1=$ effect of control diet (treatment 1 vs. treatments $2,3,4,5,6$ and 7), $C 2=$ effect of starter diets (treatments 2,3 and 4 vs. treatments 5,6 and 7), C3 = effect of rapeseed and additional pea (treatments 2 and 5 vs. treatments $3,4,6$ and 7), C4 = effect of pea levels (treatments 3 and 6 vs. treatment 4 and 7 ), C5 = interaction C $2 * C 3$ and C $6=$ interaction $\mathrm{C} 2{ }^{*} \mathrm{C} 4 ;{ }^{a-d}$ Means within rows with different superscripts are significantly different from each other by Tukey's test at $\mathrm{p}<0.05$; $\mathrm{N}$ $=7$ for groups $2-7$, for group $1 \mathrm{~N}=6$ and $\mathrm{SEM}=1.08 * \mathrm{SEM}$

Breast muscle percentage was statistically significantly higher in broilers fed with soybean meal diet than broilers fed with rapeseed meal and/or peas (Table 7) $(p<0.0001)$. Broilers fed with rapeseed meal and pea had also higher breast muscle percentage than broilers fed only with rapeseed meal $(p<0.0001)$. Also breast muscle yield increased statistically significant with increasing pea inclusion $(p<0.0001)$. There was no statistically significant difference in abdominal fat percentage between control and treatment groups, but abdominal fat percentage is significantly lower when peas were added to diets and when level of pea inclusion was higher. There were no differences in the proportional weight of the thyroid glands between control group and the birds fed with rapeseed meal diet.

Table 7. The effect of diets with soybean meal (SB), rapeseed meal (R), or rapeseed meal and peas (P) on mean broiler breast muscle and abdominal fat percentages, and thyroid gland weight

\begin{tabular}{|c|c|c|c|c|c|c|c|c|}
\hline Group & 1 & 5 & 6 & 7 & & & & \\
\hline Treatment & C & R100 & R75/P25 & R50/P50 & & & $p$-values & \\
\hline Starter diet & SB & $R+P$ & $R+P$ & $R+P$ & SEM & C1 & C3 & C4 \\
\hline Breast muscle, $\%$ & $25.09^{\mathrm{a}}$ & $20.11^{d}$ & $21.71^{c}$ & $23.71^{\mathrm{b}}$ & 0.455 & $<0.0001$ & $<0.0001$ & $<0.0001$ \\
\hline Abdominal fat, $\%$ & $1.38^{\mathrm{ab}}$ & $1.56^{\mathrm{a}}$ & $1.52^{\mathrm{a}}$ & $1.18^{\mathrm{b}}$ & 0.079 & 0.0103 & 0.6822 & 0.1718 \\
\hline Thyroid gland weight, mg & 156.01 & 193.5 & & & 13.293 & 0.0629 & & \\
\hline
\end{tabular}

$\mathrm{C}=100 \%$ of the protein of the diet is from soybean meal; R100 $=100 \%$ of the protein from soybean meal in control diet replaced with protein from rapeseed meal; R75/P25 $=25 \%$ of the protein from rapeseed meal in diet R100 replaced with protein from peas; R50/ $\mathrm{P} 50=50 \%$ of the protein from rapeseed meal in diet R100 replaced with protein from peas; $\mathrm{C} 1$ = effect of control diet (treatment 1 vs. treatments 5, 6 and 7); C3 = effect of rapeseed and additional pea (treatment 5 vs. treatments 6 and 7); C4 = effect of pea levels (treatment 6 vs. treatment 7); $a-d=$ Means within rows with different superscripts are significantly different from each other by Tukey's test at $\mathrm{p}<0.05$; breast muscle and abdominal fat: $\mathrm{N}=14$ for groups 5-7, for group $1 \mathrm{~N}=12$ and SEM = 1.08*SEM; Thyroid gland weight: $\mathrm{N}=13$ for group 5, $\mathrm{N}=12$ for group 1 and $\mathrm{SEM}=1.04 * \mathrm{SEM}$

\section{Litter quality}

Litter DM content was the lowest in groups fed soybean meal (Table 8). There were no differences between the starter diets and between the inclusion levels of pea, but there was an almost statistically significant difference in litter DM between groups fed rapeseed meal without peas and groups fed with additional peas. Broilers fed rapeseed meal but no peas had drier litter than those fed rapeseed meal and peas. 
Table 8. The effect of diets with soybean (SB) meal, rapeseed meal (R), or rapeseed meal and peas (P) on mean litter dry matter (DM)

\begin{tabular}{|c|c|c|c|c|c|c|c|c|c|c|c|c|c|c|}
\hline Group & 1 & 2 & 3 & 4 & 5 & 6 & 7 & & & & & & & \\
\hline $\begin{array}{l}\text { Treat- } \\
\text { ment }\end{array}$ & C & R100 & $\begin{array}{l}\text { R75/ } \\
\text { P25 }\end{array}$ & $\begin{array}{l}\text { R50/ } \\
\text { P50 }\end{array}$ & R100 & $\begin{array}{l}\text { R75/ } \\
\text { P25 }\end{array}$ & $\begin{array}{l}\text { R50/ } \\
\text { P50 }\end{array}$ & & \multicolumn{6}{|c|}{$p$-values } \\
\hline $\begin{array}{l}\text { Starter } \\
\text { diet }\end{array}$ & SB & SB & SB & SB & $R+P$ & $R+P$ & $R+P$ & SEM & $\mathrm{C} 1$ & C2 & C3 & C4 & C5 & C6 \\
\hline $\begin{array}{l}\text { Litter } \\
\text { DM, \% }\end{array}$ & $51.45^{c}$ & $59.84^{\mathrm{ab}}$ & $59.84^{\mathrm{ab}}$ & $55.67^{\mathrm{abc}}$ & $62.01^{\mathrm{a}}$ & $53.48^{\mathrm{bc}}$ & $58.29^{\mathrm{ab}}$ & 2.628 & 0.032 & 0.811 & 0.081 & 0.906 & 0.382 & 0.102 \\
\hline
\end{tabular}

$C=100 \%$ of the protein of the diet is from soybean meal; R100 $=100 \%$ of the protein from soybean meal in control diet replaced with protein from rapeseed meal; R75/P25 $=25 \%$ of the protein from rapeseed meal in diet R100 replaced with protein from peas; R50/P50 = $50 \%$ of the protein from rapeseed meal in diet R100 replaced with protein from peas; $\mathrm{C} 1=$ effect of control diet (treatment 1 vs treatments $2,3,4,5,6$ and 7), C2 = effect of starter diets (treatments 2, 3 and 4 vs treatments 5, 6 and 7), C3 = effect of rapeseed and additional pea (treatments 2 and 5 vs treatments 3, 4, 6 and 7), C4 = effect of pea levels (treatments 3 and 6 vs treatment 4 and 7), C5 = interaction C2* C3 and $\mathrm{C} 6$ = interaction $\mathrm{C} 2{ }^{*} \mathrm{C} 4$; ${ }^{\mathrm{a}-\mathrm{d}}$ Means within rows with different superscripts are significantly different from each other by Tukey's test at $p<0.05 ; \mathrm{N}=7$ for groups $2-7$, for group $1 \mathrm{~N}=6$ and SEM $=1.08 * \mathrm{SEM}$

\section{Meat quality}

In the sensory quality evaluation there were no differences between the protein sources in juiciness or tenderness of breast meat. However, taste was significantly better in the experimental treatment groups than in the control group (Table 9).

Table 9. Mean sensory quality of broiler breast muscle in response to diets with soybean (SB) meal, rapeseed meal (R), or rapeseed meal and peas (P)

\begin{tabular}{|c|c|c|c|c|c|c|c|c|}
\hline Group & 1 & 5 & 6 & 7 & & & & \\
\hline Treatment & C & R100 & R75/P25 & R50/P50 & & & $p$-values & \\
\hline Starter diet & SB & $R+P$ & $R+P$ & $R+P$ & SEM & $\mathrm{C} 1$ & $\mathrm{C} 3$ & C4 \\
\hline Tenderness & 6.17 & 5.9 & 6.17 & 6.07 & 0.211 & 0.6815 & 0.4422 & 0.7854 \\
\hline Juiciness & 4.90 & 5.29 & 5.54 & 5.14 & 0.166 & 0.0738 & 0.8014 & 0.1624 \\
\hline Flavour & $5.50^{\mathrm{bc}}$ & $5.86^{a}$ & $5.88^{\mathrm{a}}$ & $5.72^{\mathrm{ab}}$ & 0.105 & 0.0383 & 0.6538 & 0.3699 \\
\hline
\end{tabular}

$\mathrm{C}=100 \%$ of the protein of the diet is from soybean meal; R100 $=100 \%$ of the protein from soybean meal in control diet replaced with protein from rapeseed meal; R75/P25 = 25\% of the protein from rapeseed meal in diet R100 replaced with protein from peas; R50/P50 = 50\% of the protein from rapeseed meal in diet R100 replaced with protein from peas; C1 = effect of control diet (treatment 1 vs treatments 2, 3, 4, 5, 6 and 7), C2 = effect of starter diets (treatments 2,3 and 4 vs treatments 5,6 and 7), C3 = effect of rapeseed and additional pea (treatments 2 and 5 vs treatments $3,4,6$ and 7), $C^{4}=$ effect of pea levels (treatments 3 and 6 vs treatment 4 and 7), C5 = interaction C2*C3 and C6 = interaction $\mathrm{C} 2 * \mathrm{C} 4$; ${ }^{\mathrm{a}-\mathrm{c}}$ Means within rows with different superscripts are significantly different from each other by Tukey's test at $p<0.05$; $\mathrm{N}=7$ for groups 5-7, for group $1 \mathrm{~N}=6$ and $\mathrm{SEM}=1.08 * \mathrm{SEM}$

The effect of rapeseed meal and pea meal inclusion on fatty acid profile of broiler breast meat is shown in Table 10. Birds fed with either rapeseed meal or rapeseed meal and peas had lower content of myristic acid $(p<0.0001)$, palmitic acid $(p<0.0001)$ and stearic acid $(p=0.0397)$ in breast meat than birds fed with soybean meal. In contrast, birds fed with either rapeseed meal or rapeseed meal and peas had higher content of linoleic acid $(p=0.0373)$, linolenic acid $(p<0.0001)$, DPA $(p=0.0002)$ and DHA $(p=0.0011)$ in breast meat than control group. There was also a statistically significant difference between the experimental groups: The breast meat of the broilers fed with rapeseed meal without peas had significantly higher oleic acid $(p=0.0122)$ and linolenic acid $(p=0.0122)$ content than the meat of the broilers fed with rapeseed meal and peas.

In total, the breast meat contained less saturated $(p<0.0001)$ and more polyunsaturated fatty acids $(p=0.0012)$ in the experimental groups than in the control group. There was no difference in the content of total monounsaturated fatty acids between the experimental groups and the control group. The content of the saturated fatty acids decreased with the additional peas in the diet $(p=0.0593)$. There were more omega-3 $(p<0.0001)$ and omega- 6 -fatty acids $(p=0.0730)$ in the breast meat of the birds in the experimental groups than in the control group, and the omega-6/omega-3- ratio of the breast meat was smaller in the experimental groups than in the control group $(p<0.0001)$. In addition, the omega-6/omega-3- ratio was lower in the breast meat of the birds fed with the rapeseed meal diet than in the breast meat of the birds fed with the rapeseed meal and pea diets $(p=0.0183)$. 
Table 10. Mean fatty acid composition of broiler breast meat lipids in response to diets with soybean meal (SB), rapeseed meal $(R)$, or rapeseed meal and peas $(P)$

\begin{tabular}{|c|c|c|c|c|c|c|}
\hline Group & 1 & 5 & 7 & & \multirow{2}{*}{\multicolumn{2}{|c|}{$p$-values }} \\
\hline Treatment & C & R100 & R50/P50 & \multirow[b]{2}{*}{ SEM } & & \\
\hline Starter diet & SB & $\mathrm{R}+\mathrm{P}$ & $R+P$ & & $\mathrm{C} 1$ & C3 \\
\hline \multicolumn{7}{|l|}{ Fatty acid } \\
\hline $\mathrm{C}_{14: 0}$ (Myristic) & $0.62^{\mathrm{a}}$ & $0.37^{b}$ & $0.36^{\mathrm{b}}$ & 0.026 & $<0.0001$ & 0.9233 \\
\hline$C_{16: 0}($ Palmitic) & $21.75^{a}$ & $16.75^{b}$ & $16.52^{b}$ & 0.314 & $<.00001$ & 0.6109 \\
\hline $\mathrm{C}_{18: 0}$ (Stearic) & $7.96^{\mathrm{a}}$ & $6.52^{\mathrm{b}}$ & $7.32^{\mathrm{a}}$ & 0.362 & 0.0397 & 0.1390 \\
\hline $\mathrm{C}_{18: 1}$ cis 9 (Oleic) & $32.95^{\mathrm{b}}$ & $36.25^{\mathrm{a}}$ & $32.27^{b}$ & 1.005 & 0.3250 & 0.0122 \\
\hline $\mathrm{C}_{18: 1}$ cis 11 (Vaccinic) & $3.48^{\mathrm{b}}$ & $4.62^{\mathrm{ab}}$ & $5.55^{\mathrm{a}}$ & 0.398 & 0.0062 & 0.1189 \\
\hline$C_{18: 2}$ (Linoleic) & $15.47^{b}$ & $16.98^{\mathrm{a}}$ & $16.91^{\mathrm{ab}}$ & 0.507 & 0.0373 & 0.9241 \\
\hline$C_{18: 3}(\alpha$-Linolenic $)$ & $1.54^{c}$ & $4.23^{\mathrm{a}}$ & $3.45^{b}$ & 0.198 & $<0.0001$ & 0.0122 \\
\hline $\mathrm{C}_{20: 4}$ (Arachidonic) & 2.60 & 2.57 & 3.36 & 0.293 & 0.3490 & 0.0752 \\
\hline $\mathrm{C}_{20: 5}(\mathrm{EPA})$ & 0.50 & 0.47 & 0.56 & 0.070 & 0.8868 & 0.4077 \\
\hline$C_{22: 5}(D P A)$ & $0.68^{b}$ & $1.69^{\mathrm{a}}$ & $1.85^{\mathrm{a}}$ & 0.179 & 0.0002 & 0.5182 \\
\hline$C_{22: 6}(D H A)$ & $0.53^{b}$ & $1.60^{\mathrm{a}}$ & $1.42^{\mathrm{a}}$ & 0.194 & 0.0011 & 0.5221 \\
\hline \multicolumn{7}{|l|}{ Summary } \\
\hline SFA & $31.31^{\mathrm{a}}$ & $24.38^{b}$ & $25.43^{b}$ & 0.369 & $<0.0001$ & 0.0593 \\
\hline MUFA & 44.54 & 46.63 & 44.45 & 1.165 & 0.5157 & 0.2031 \\
\hline PUFA & $24.20^{\mathrm{b}}$ & $29.00^{\mathrm{a}}$ & $30.12^{\mathrm{a}}$ & 1.082 & 0.0012 & 0.4719 \\
\hline Omega-3 & $4.74^{\mathrm{b}}$ & $8.49^{a}$ & $8.15^{\mathrm{a}}$ & 0.385 & $<0.0001$ & 0.5485 \\
\hline Omega-6 & 19.41 & 20.50 & 21.94 & 0.736 & 0.0730 & 0.1835 \\
\hline Omega-6/ Omega-3 & $4.10^{\mathrm{a}}$ & $2.44^{c}$ & $2.70^{b}$ & 0.070 & $<0.0001$ & 0.0183 \\
\hline
\end{tabular}

\section{Discussion}

\section{Experimental diets}

The analysed compositions of the feeds differed from the calculated compositions. Especially crude protein content was actually considerably higher in all diets. Nevertheless, the differences between experimental groups are invisible and the crude protein contents were actually closer to recommended values for Ross 308 birds. According to manual for Ross 308 birds (Ross Broiler Nutrition Specification, Aviagen Group ${ }^{\circledR}$ ), diets' crude protein content should be $230 \mathrm{~g} \mathrm{~kg}^{-1} \mathrm{DM}$ for starter period ( 1 to 10 days), $215 \mathrm{~g} \mathrm{~kg}^{-1} \mathrm{DM}$ for growing period (11 to 24 days) and $195 \mathrm{~g} \mathrm{~kg}^{-1} \mathrm{DM}$ for finisher period ( 25 days to slaughter) when bird's target weight is $1.7-2.4 \mathrm{~kg}$. Energy content for starter, growing and finisher periods should be for 12.55, 12.97 and $13.39 \mathrm{MJ} \mathrm{kg}^{-1}$, respectively. Both energy and crude protein levels are lower in this study. The objective of this study was to replace all soybean meal in feeds with rapeseed meal and/or pea meal. This objective unfortunately couldn't be reached with these cultivars used. The pea cv. Karita is white-flowered and modern spring cultivar, which shouldn't contain harmful levels of ANFs. Karita has been used successful in feeding laying hens (Koivunen et al. 2015), although inclusion levels for laying hens were smaller $\left(100,200\right.$ and $\left.300 \mathrm{~g} \mathrm{~kg}^{-1} \mathrm{DM}\right)$ than in this experiment. Also rapeseed cv. Cordelia is the most common cultivar in Finland and is used for feeding dairy cows. Unfortunately the ANF content of pea and rapeseed wasn't analysed because lack of proper analysing technique at the time. 


\section{Bird performance}

Performance of the birds fed with soybean meal diet was superior compared to that of the birds fed with rapeseed meal and pea based diets. We found that bird performance was the poorest and mortality the highest when birds received diets based on rapeseed meal. Other studies support this finding. High rapeseed inclusion in broiler diets degraded performance in studies of McNeill et al. (2004), Taraz et al. (2006), Toghyani et al. (2009), and Szymeczko et al. (2010). In the current study mortality and cumulative mortality in the experimental groups that received rapeseed meal were notably high. Mortality rate increased after 20 days the experiment was started. Not many dead birds were found, but high mortality was due to high culling rate. Most birds were culled if they were smaller than $50 \%$ of the birds in same pen in order to avoid welfare problems. This increased the mortality of the experiment groups that received rapeseed meal or rapeseed and pea meal as a starter diet. Szymeczko et al. (2010) found that the negative effect of a high dietary level of whole rape seeds was much clearer in young birds than in more mature birds. We found indications that the starter diets (soybean or rapeseed and pea) had a long-lasting effect on broiler performance: birds on rapeseed meal and pea starter diet had significantly inferior growth, smaller body weight, lower feed intake, and poorer FCR in starter period and during the whole growing period.

In the current study we used a double zero variety rapeseed, which contains very little glucosinolates and erucic acid (Bell 1993), but it replaced the soybean meal in the experimental diet entirely. However, more likely than glucosinolates, the fibre content of rapeseed meal reduced the digestibility of the experimental diets and therefore affected performance.

In the current study, inclusion of peas with rapeseed meal in the diet improved birds' performance and decreased culling rate, although there was still a significant difference compared to the soybean meal control diet. Fasina and Campbell (1997) found that whole rapeseed and pea in a diet at the $10 \%$ level, replacing soybean meal, decreased broiler performance, but they observed no further reduction in performance at the levels of 20 or $30 \%$. According to Toghyani et al. (2009), including whole rapeseed and rapeseed meal at the 5, 10 or $15 \%$ levels linearly reduced performance. Similarly, FCR increased, feed intake and body weight decreased when dietary pea level was increased (Cowieson et al. 2003, McNeill et al. 2004, Moschini et al. 2004). McNeill et al. (2004) found that the presence of trypsin inhibitors were likely to have an effect on intake as well as diet utilization. Cowieson et al. (2003) suggested that pea had a main effect on poor bird performance. They found that bird performance was better with different pea cultivars, so they suggested that the difference is due to starch composition and structure. Peas contain lot of starch and the nutritive value of starch is variable and depends on the ratio of amylose to amylopectin. Starches with higher concentration of amylopectin might be more digestible than starches with amylase. Cowieson et al. (2003) also found that by increasing exogenous enzymes to feed the performance could be increased. Especially xylanases, $\beta$-glucanases and phytase are enzymes that will aid performance through removal of ANF, breaking cell walls, releasing phytate phosphorus, improving protein digestibility and provision of substrates for beneficial microflora. In this experiment Betafin ${ }^{\circledR}$ and Roxazyme $G 2^{\circledR}$ enzymes was used in experimental feeds. These exogenous enzyme additions could have possibly increased performance but it's impossible to prove. In this experiment all experimental groups got enzyme addition because these particular enzyme products are commonly used and they support birds' performance when fed with experimental feed. Cowieson et al. (2003) wound that addition of the similar enzyme cocktail improved gain and feed conversion in birds fed on pea-based diets. Especially the presence of xylanase activity in the enzyme supplement may have been responsible for better weight gain and FCR. Although this positive effect might be result of xylanases affecting the wheat arabinoxylans or pea carbohydrates, the exogenous enzyme addition is recommended to feeds containing pea meal.

We found that breast muscle size and carcass weight decreased when the inclusion of rapeseed in diets was higher. These variables correlate with body weight, which also was lower in rapeseed meal diets than in control diet. In agreement, Kocher et al. (2001) reported that the replacement of soybean meal with rapeseed meal had a significant effect on the carcass weight. Also Taraz et al. (2006) found similar effect of rapeseed meal on carcass weight: When soybean meal was replaced entirely with rapeseed meal, carcass weight was significantly lower. When a replacement of 25,50 or $75 \%$ of soybean meal with rapeseed meal was used, there was no significant difference in carcass weight. In this study the inclusion of peas increased breast muscle size and decreased abdominal fat. In contrast to earlier studies, we found that rapeseed meal increased abdominal fat, whereas in studies of Taraz et al. (2006) and Toghyani et al. (2009) higher inclusion of rapeseed meal decreased abdominal fat content. Crespo and Esteve-Garcia (2001) suggested that polyunsaturated fatty acid (PUFA) produce lower abdominal fat deposition in broilers than saturated or monounsaturated fatty acids. Our results are not that clear, because we found that with pea in the diet, abdominal fat content was lower than with control or rapeseed diets, but PUFA content was higher with pea in the diet and in rapeseed diet than in soybean diet. Although, the energy to protein ratio was higher in control diet than in other diets. 


\section{Meat quality}

In the sensory quality evaluation, there was no indication that meat from experimental groups would be less acceptable to evaluators than the meat from the control group. The panel indicated no fishy taint in meat from the experimental groups. In fact the flavour was evaluated to be better in the experimental groups than in the control group. Especially meat from birds that received the rapeseed meal diet and R75/P25-diet seemed to have a better flavour than the control group. McNeill et al. (2004) found similar results on sensory quality: The meat from broilers that received $200 \mathrm{~g} \mathrm{~kg}^{-1}$ rapeseed in feed was identified as different, but the meats from all dietary treatments were acceptable to consumers.

Rahimi et al. (2011) presented that fatty acid composition of the birds' tissues generally reflect the fatty acid profile of the diet. We found that dietary rapeseed meal inclusion clearly improved the fatty acid profile of broiler breast meat. In the current study, there were less saturated and more polyunsaturated fatty acids in the breast meat of the birds fed with rapeseed meal diet, and the rapeseed meal and pea diets than in the breast meat of the birds fed with soybean meal diet. Similarly Rahimi et al. (2011), who used diet with $15 \%$ of whole rapeseed, observed that the content of PUFA and omega-3 of the breast meat of birds on that diet was higher than that of the birds on soybean meal and maize based control diet.

Dietary omega-3 fatty acids have been reported to aid in the prevention of certain diseases, especially cardiovascular disorders (Simopoulos 2004). In human diet omega-6/omega-3-ratio should be 1, but in Western societies it is normally 10-20 (Simopoulos 2004). Western diets are deficient in omega-3 fatty acids, and have excessive amounts of omega- 6 fatty acids compared with the diet on which human beings evolved and their genetic patterns were established. Excessive amounts of omega- 6 fatty acids promote the pathogenesis of many diseases, including cardiovascular disease and cancer, whereas increased levels of omega-3 PUFA (a lower omega-6/omega -3 ratio), exert suppressive effects (Simopoulos 2004). In this study, the omega-6/omega-3-ratio of the broiler breast meat was $4.1 ; 2.4$ and 2.7 for soybean meal, rapeseed meal, and rapeseed meal and peas based diets, respectively. Health authorities have recommended increases in the consumption of omega- 3 fatty acids, especially $\alpha$-linolenic acid (ALA, $C_{18: 3}$ ) and its long-chain metabolites eicosapentaenoic acid (EPA, $C_{20: 5}$ ) and docosahexaenoic acid (DHA, $C_{22: 6}$ ) (Mantzioris et al. 2000). ALA is present in vegetable oils like rapeseed and consumption of ALA increases also EPA. In this study, ALA and DHA contents of broiler breast muscle were substantially higher in the breast muscle of birds which received rapeseed meal and rapeseed meal and pea diets than in breast meat of birds on soybean meal diet.

Overall, diet based solely on rapeseed meal protein is not suitable for broiler production, although it clearly improved the fatty acid profile of the meat. However, this beneficial effect is also achieved with moderate dietary levels of rapeseed meal along with additional pea protein in the diet.

\section{Acknowledgements}

The authors would like to acknowledge the financial support provided for this study by Raisioagro Oy. They would also like to thank technical and laboratory staff of Luke Natural Resources Institute Finland for their input in taking care of the experimental birds and for the chemical analyses and meat quality analyses.

\section{References}

AOAC (1990) Official methods of analysis. Association of official analytical chemists, Inc., Arlington, VA. 1298 p.

Barbour, G.W. \& Sim, J.S. 1990. True metabolizable energy and true amino acid availability in canola and flax products for poultry. Poultry Science 70: 2154-2160.

Bedford, M.R. \& Schulze, H. 1998. Exogenous enzymes for pig and poultry. Nutrition Research Reviews 11: 91-114.

Bell, J.M. 1993. Factors affecting the nutritional value of canola meal: A review. Canadian Journal of Animal Science 73: 679-697.

Chen, S. \& Andreasson, E. 2001. Update of glucosinolates metabolism and transport. PlantPhysiology and Biochemistry 39: 743-758.

Cowieson, A.J., Acamovic, T. \& Bedford, M.R. 2003. Supplementation of diets containing pea meal with exogenous enzymes: effects on weight gain, feed conversion, nutrient digestibility and gross morphology of the gastrointestinal tract of growing broilerchicks. British Poultry Science 44: 427-437.

Crespo, N. \& Esteve-Garzia, E. 2001. Dietary fatty acid profile modifies abdominal fat deposition in broiler chickens. Poultry Science 80: 71-78.

Fasina, Y.O \& Campbell, G.L. 1997. Whole canola/pea and whole canola/canola meal blends in diets for broiler chickens 2. Determination of optimal inclusion levels. Canadian Journal of Animal Science 77: 191-195. 
Halkier, B.A \& Gershenzon, J. 2006. Biology and biochemistry of glucosinolates. Annual Review of Plant Biology 57: 303-333. Jeroch, H., Kracht, W. \& Dänicke, S. (2001) Feeding value of rape products and its improvement for broilers and laying hens. European Journal of Lipid Science Technology 103: 7-11.

Kocher, A., Choct, M., Morrisroe, L. \& Broz, J. 2001. Effects of enzyme supplementation on the replacement value of canola meal for soybean meal in broiler diets. Australian Journal of Agricultural Research 52: 447-452.

Koivunen, E., Tuunainen, P., Valaja, J. \& Valkonen, E. 2015. Use of semi-leafless peas (Pisum sativum L) in laying hen diets. Agricultural and Food Science 24: 84-91.

Luke 2014. Finnish Feed tables and nutrient requirements. www.luke.fi/feedtables.

Mantzioris, E., Cleland, L.G., Gibson, R.A., Neumann, M.A., Demasi, M. \& James, M.J. 2000. Biochemical effects of a diet containing foods enriched with n-3 fatty acids. The American Journal of Clinical Nutrition 72: 42-48.

McNeill, L., Bernard, K. \& McLeod, M.G. 2004. Food intake, growth rate, food conversion and food choice in broilers fed on diets high in rapeseed meal and pea meal, with observations on sensory evaluation of the resulting poultry meat. British Poultry Science 45: 519-523.

Moschini, M., Masoero, F., Prandini, A., Fusconi, G., Morlacchi, M. \& Piva, G. 2004. Raw pea (Pisum sativum), raw faba bean (Vicia faba var. minor) and raw lupin (Lupinus albus var. multitalia) as alternative protein sources in broiler diets. Italian Journal of Animal Science 4: 59-69.

Rahimi, S., Kamran Azad, S. \& Karimi Torshizi, M.A. 2011. Omega-3 enrichment of broiler meat by using two oil seeds. Journal of Agricultural Science and Technology 13: 353-363.

Simopoulos, A.P. 2004. Omega-6/Omega-3 Essential fatty acid ratio and chronic diseases. Food Reviews International 20: 77-90.

Slover, H. \& Lanza, E. 1979. Quantitative analysis of food fatty acids by capillary gas chromatography. Journal of American Oil Chemists' Society 56: 933-943.

Szymeczko, R., Topolínski, T., Burlokowska, K., Piotrowska, A., Boguslawska-Tryk, M. \& Blaszyk, J. 2010. Effects of different levels of rape seeds in the diet on performance, blood and bone parameters of broiler chickens. Journal of Central European Agriculture 11: 393-400.

Taraz, Z., Jalali, S.M.A., \& Refeie, F. 2006. Effects of replacement of soybean meal with rapeseed meal on organs weight, some blood biochemical parameters and performance of broiler chicks. International Journal of Poultry Science 5: 1110-1115.

Toghyani, M., Mohammad Salehi, A., Gheisari, A. \& Tabeidian, S.A. 2009. The effect of low-glucosinolate rapeseed meal in diets with multi-enzyme supplement on performance and protein digestibility in broiler chicks. Journal of Animal and Feed Sciences 18: $313-321$. 